\title{
Grzeczność zobowiązuje, niegrzeczność prowokuje - o grzeczności i stosowności w reklamie
}

Ewa Szczęsna 
napos Seria X $20(14$

\section{Ewa Szczęsna}

\section{Grzeczność zobowiązuje, niegrzeczność prowokuje - o grzeczności i stosowności w reklamie}

W Te współczésnej reklamie odnaleźć można całą gamę zachowań, poczynając od niestosowności, operowania poetyką skandalu, przez nmiej lub bardziej oficjalną uprzejmość, deklarowanie osobistej życzliwości, aż po rodzaj uniżonej grzeczności, powiązanej często ze schlebianiem odbiorcy. Grzeczność i niegrzeczność, stosowność i niestosowność nie tyle odnoszą się tu bezpośrednio do realizacji norm kulturowych lub polemiki z nimi, co są 11 arzędziem oddziaływania 11 a odbi or cę. A zatem już samym ich nżyciu można by dopatrywać się zlamania zasady stosowności (gdyż stosowność nie jest tu sprawa odpowiedniości, ale perswazji). Można by, gdyby nie fakt, iz mamy do czynienia z przekazem, w którym dominującą funkcję pelni perswazja uzasadniająca przesunięcia w sférze użyć formul językowych, przedstawień obrazowych i dźwiękowych, prezentacji zdarzeń, zachowań, wyglądów istniejących w określony sposób w świadomości społecznej. Oznacza to, że istotnym czynnikiem, jaki należałoby wziąć pod uwagę, oceniając stosowność jakiegoś elementu w przekazie kulturowym, jest kontekst gatunkowy. Ten sam element tekstowy może być odbierany jako stosowny lub niestosowny w zależności od tego, czy znajdzie się w tekście informacji prasowej, utworze artystycznym, piśmie urzędowym czy reklamie.

Z punktu widzenia dzialań reklamowych stosowne w reklamie jest przede wszystkim to, co jest skuteczne, dlatego nic może być tu mowy o raz na zawsze ustalonych zasadach stosowności. Zasady te ustanawiane są niemal każdorazowo, warunkowane przedmiotem i celem reklamy.

Nadrzędność perswazji, podporządkowanie jej innych funkcji (informacyjnej, estetycznej) oraz elementów struktury przekazu, sprawiają, że pojawiające się w reklamie motywy tematyczne pelnią przede wszystkim funkcję c h w y tó w te ks t ow y c h. Podobnie na ocenę grzeczności czy stosowności ma wpływ kontekst komunikacyjny - zarówno wewnątrztek- 
stowy (prezentowane zdarzenie, bohaterowie, przedmiot reklamy, czas i miejsce zdarzeń), jak i zewnątrztekstowy (odbiorca reklamy, tematyka innych reklam czy przekazów kulturowych, wśród których reklama się ukazuje, kontekst rzeczywistych zdarzeń, norm zachowań przyjętych w danej kulturze). I tak na przykład za niestosowne, obraźliwe czy prowokacyjne może być uznane umieszczenie śmialych obyczajowo reklam w pobliżu miejsc kultu religijnego, przerywanie nimi programów odnoszących się do ważnych problemów narodowych, społecznych (na przykład problemu głodu na świecie czy cierpienia ludzi w wyniku wojen i kataklizmów).

Istotną rolę odgrywa też stopień dostosowania przekazu do przedmiotu reklamy oraz do wieku, ptci, wykształcenia odbiorcy. To, co w reklamie kierowanej do ludzi młodych uchodzi za stosowne i atrakcyjne, może okazać się niestosowne czy obraźliwe w reklamie kierowanej do ludzi starszych. Dotyczy to zwłaszcza użytego w przekazie języka, ale także muzyki, ubioru i zachowań bohaterów, czy prezentowanych zdarzeń. I lasło: „Tak zajebisty, że kręci każdego" wraz z towarzyszącą mu muzyką hip-hopową może uchodzić za stosowne w reklamie nowego napoju dla mlodzieży, nie zostanie jako takie uznane w reklamie funduszu emerytalnego czy zestawu witamin dla osób starszych. I odwrotnie, grzeczność, która oceniana jest przez ludzi dorosłych, wykształconych, realizujących normy zachowań kulturowych jako stosowna niemal w każdej sytuacji, w środowiskach grup młodzieżowych może być w wielu sytuacjach oceniana jako niestosowna, deprecjonująca osobę grzeczną. Podobnie oburzać i szokować może reklama społeczna ukazująca kobietę w sytuacji zbliżenia seksualnego z kościotrupem. Jednak zamieszczone obok hasto: „AIDS to martwy temat” oraz informacja o ilości zakażeń wirusem HIV sprawiają, że śmiale przedstawienie zostaje uzasadnione. Waga i charakter problemu usprawiedliwiają użyte środki oddziaływania, które mają wstrząsnąć odbiorcą i wpłynąć na jego zachowania. Przedstawienie może nadal szokować, nie będzie jednak - w kontekście całego kommikatu i poruszanego problemu - uznane za calkiem niestosowne (choć element niestosowności zawarty jest w kształtowaniu i utrwalaniu stereotypu związanego ze sposobami zarażenia się wirusem I IIV).

Zarówno grzeczność i stosowność, jak i niegrzeczność oraz niestosowność funkcjonują w reklamie na wielu płaszczyznach. Obecne są w sferze języka (tu na przykład zwroty grzecznościowe czy też grzeczność i niegrzeczność zawarte w semantyce wypowiedzi językowej, tonacji wypowiedzi), w sferze obrazu (chociazby w sposobie zachowania prezentowanych postaci: ich gestykulacji, ekspresji mimicznej, ruchach ciała, ubiorze') i dźwięku (na przykład w dostosowaniu lub niedostosowaniu głośności, charakteru muzyki do odbiorcy i przedmiotu reklamy). Niekiedy zachowania grzecznościowe bywają tematem reklamy (jak w reklamack: społecznych), jednak zasadniczo pelnią one funkcję ch w y t u re k l a mowe go, uczestnicząc w realizacji dominującej funkcji perswazyjnej, której podporządkowane zostają innt funkcje związane z aktem grzecznościowym. 
Jedną z takich funkcji jest nawiązanie kontaktu, w którym ważne niejsce zajmują zwroty grzecznościowe. Dotyczy to zwhaszcza formul powitania, których perswazyjny aspekt wyraża się w angażowaniu odbiorcy w akt komunikacji. Dobrego przykładu dostarcza tu hasło "Dzień dobry Coca-Cola”, gdzie poza dążeniem do nawiązania kontaktu z odbiorcą komunikowane są: zwrot do wszystkich odbiorców (i tak na przykład zastąpienie „dzień dobry” formulą „cześć” ograniczałoby adresata do kręgu dobrych znajomych lub ludzi młodych) oraz codzienność i zwyczajność kontaktu („dzicú dobry” jest częściej stosowane i mniej nacechowane stylistycznie niż, powiedzmy, „witam”). Ta najczęściej stosowana i uznawana za whaściwą we wszystkich typach kontaktu formula powitania wprowadza przedmiot reklamy w sferę tego, co uniwersalne, powszechne. Dodatkowo, uczynienie formuly grzecznościowej częścią sloganu pozwala na wprowadzenie swoistej gry językowej, polegającej na kondensacji kilku sytuacji komunikacyjnych, jak: powitania wypowiadanego przez upersonifikowany przedmiot polączonego z przedstawieniem się; powitania połączonego z częstowaniem („dzień dobry, czy zechcialby/zechcialaby pan/pani napić się Coca-Coli, czy ma pan/pani ochotę na...") oraz zwrotu do przedmiotu reklanny. Kondensacja funkcji i wprowadzenie gry z odbiorcą służą ekonomizacji przekazu i zaangażowaniu odbiorcy w akt komunikacji.

Formuly grzecznościowe ponadto (jak prośba, zaproszenie do nczestnictwa w czymś, zrobienia czegoś, podziçkowanie) mogą być o wiele bardzicj skuteczne perswazyjnie niż bezpośredni rozkaz. W postawie grzeczności zawarta jest zdolność do sterowania odbiorcą. I tak, uprzejme zapytywanie o coś z o b o w i ą z u je odbiorcę do równie uprzejmej odpowiedzi, zaś grzeczna prośba stwarza zachętę do jej spełnienia - zgodnie z istniejącym kanonem zachowań.

Jeszcze bardziej skuteczne perswazyjnie jest posłuzenie się komplementem czy pochwała —oczym już w starożytności przekonywały bajki Ezopa, a co współczéśnie analizowane jest przez psychologów społecznych. Według Roberta Cialdiniego wszyscy jesteśmy „niesłychanie lapczywymi pożeraczami komplementów". Znaczuie bardziej lubimy tych, którzy nam schlebiają, niż tych, którzy nas krytykują — nawet (a może zwłaszcza) wówczas, gdy na komplementy nie zashıżyliśny, a na krytykę tak. Nawet jeśli jesteśny wobec pochlebców powściągliwi, tatwiej ulegamy ich perswazji. Stąd reklama chętnie odwołıje się do komplementu, schlebiania odbiorcy. „Ty też możesz być jak on” czy „ona“ — mówi, prezentując sylwetki mlodych, pięknych, atrakcyjnych ludzi, którym powiodło się w życiu — „Ty też jesteś tego warta; zasłużyleś na to, by zadbała o ciebie najlepsza [w domyśle: nasza] firma". Schlebianie w reklamie odbywa się na drodze utożsamienia odbiorcy i jego świata ze światem prezentowanym w przekazie, składanej nieustannie obietnicy uczynienia świata odbiorcy doskonalszym. Prezentując postawę „uprzejmego” przekonywania o podobieństwie odbiorcy do reklamowych bohaterów - ludzi odnoszących sukcesy, atrakcyjnych fizycznie i grzecznych —

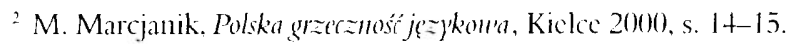

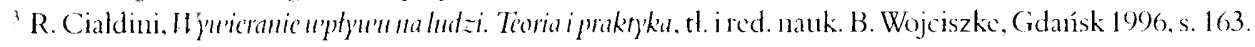


przekaz reklamowy odwoluje się do charakterystycznej dla nas skłonności do obdarzania większą sympatią i zaufaniem tych, których uważamy za sympatycznych i podobnych do nas ${ }^{4}$.

Postawa grzeczności jest dla reklamy (podobnie jak i dla innych form tekstualności, a przede wszystkim relacji międzyludzkich) niezmiernie korzystna. Przede wszystkim jest niezbywalnym warunkiem zaistnienia w systemic norm kulturowych — czyli tego, co oficjalne, ogólne, obowiązujące. Dla reklamy odwołanie się do grzeczności i stosowności jest sposobem na wrowadzenie przedmiotu reklamy w przestrzeń systemu k u I t u ry: zachowań, które sa powszechnie akceptowane, uważane przez daną społeczność za pożądane, dobre - a zatem etyczne. Są to również zachowania, które postrzegane są jako gwarancja ladu, klarowności relacji międzyosobowych - wpisujące się w klasyczne rozumienie piękna.

Grzeczność jest deklaracją, którą składany imnym, a która dotyczy przestrzegania określonych norm zachowań. Jest udzielaną innym gwarancją bezpieczeństwa, ale również rodzajem zapewnienia o istnieniu porządku spolecznego i społecznej hierarchii. Toteż posłuzenie się w filmie reklamowym scenką, w której dobrze wychowany malec częstuje przybyłych gości otrzymanymi od nich w prezencie reklamowanymi czekoladkami, sprzyja oddziaływaniu na decyzje konsumenckie oglądających reklamę rodziców czy dziadków, którym ukazuje się przedmiot reklamy jako „pomoc dydaktyczna” w procesie wpajania dziecka zasad grzeczności. Umieszczone w reklamie zachowanie grzecznościowe, w którym uczestniczą: dziecko, rodzina oraz przedniot reklamy, służy wpisaniu tak reklamowanych słodyczy, jak i zachowania dziecka w system tego, co akceptowane.

Jednocześnie jednak grzeczność (podobnie jak i honoryfikatywność) związana jest ze zwiększonym dystansem wobec odbiorcy, stwarzaniem efektu obcości, podczas gdy w przekazach reklamowych widoczna jest tendencja do moźliwie znacznej redukcji dystansu, a nawet calkowitego jego zniesienia. Reklamę charakteryzuje dążenie do ukazywania świata przedstawionego i nadawcy jako dostępnych i bliskich odbiorcy. Znajduje to odzwierciedlenie w formach językowych - częstszym użyciu w zwrotach do odbiorcy formy "ty” niż .pan”, „pani”. Zastosowanie form drugiej osoby: „Weź sprawy w swoje ręce”, „Teraz Twoja kolej” zaniast „Niech Pan/Pani weźmie sprawy w swoje ręce”, „Teraz Pana/Pani kolej” lub bezosobowego: „Proszę wziąć sprawy w swoje ręce” redukuje dystans nadawczo-odbiorczy. Shuży też odwołaniu się do aktywności adresata przekazu, jego otwartości na świat, nowoczesności myślenia, dlatego zawsze towarzyszy reklamom kierowanym do ludzi mlodych.

Warto dodać, że na zastappienie form grzecznościowych „pan”, „pani” bezpośrednim „ty” mialy też wpływ reklamy zachodnie - w szczególności przekazy anglojęzyczne. Ich kalkowanie związane było z przejmowaniem konsumpcyjnej kultury zachodniej - miało swoje podloże kulturowe, ale także uzasadnienie językowe: oto krótkie formy realizowały postulaı ekonomizacji języka reklany, dążenia do maksymalnej zwięzloścī̄.

${ }^{4}$ P. G. Zimbardo. F. L. Ruch. Psychologia i żric th. J. Radzicki. red. nauk. wyd. pol. M. Materska, K. Skarżyńska Warszawa 1994. s. 551.

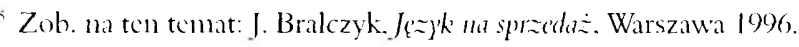


Redukcja dystansu nadiwczo-odbiorczego, aktywizacja odbiorcy i ekonomizacja wypowiedzi to zalety form zwrotu $\mathrm{w}$ drugiej osobie, które jednak nie likwidują apodyktyczności rozkazı. Ponieważ bezpośrednie powiązanie nakazu: „zrób to”, ..kup to”, „skorzystaj z naszej oferty" z przedmiotem reklamy może zostać odebrane jako niegrzeczne, zbyt natarczywe, w reklamach coraz częściej zastępuje się je nakazem pośrednim, lagodzonym zachętą czy obietnicą. I tak na przykład zamiast hasła „Kup Fiata, Lancię lub Alfę Romeo” w reklamie tych pojazdów pojawia się hasło „Zachowaj dla siebie równowartość całego podatku VAT”, z dopiskiem: „Kupując jeden z osobowych modeli Fiata, Lancii bądź Alfy Romeo, otrzymasz rabat, który zrekompensuje Ci część podatku VAT, niepodlegającą odliczeniu”. Podobnie hasto „Sprawdź osiągi swojego samochodı” zastapiło formulę „Kup opony zimowe”, zaś „Zobacz świat w nowym świetle. Kimkolwiek jestés, gdziekolwiek mieszkasz — jedna z 4457 naszych żarówek na pewno będzie Ci odpowiadać” wyparto bezpośredni nakaz: „Kup żarówki naszej firmy".

W użyciu językowych form grzecznościowych w reklamie obecne jest także dążenie do projektowan ia rze czywis tości. W formulach gratulacji czy podziękowan - gratuluje się czegoś lub dziękuje za coś, w stosunku do czego nie ma pewności, że zostało to przez odbiorcę zrobione, jak: „Gratulujemy ci nowego BMIV”; „1)ziçkujemy, że zechcialeś skorzystać z tej promocji”. Podziękowanie czy gratulacje jako akt grzecznościowy odwohują się do norm przyjętych w spotkaniu międzyosobowym: akty te są uzasadnione wówczas, gdy działanie, którego dotyczą, miało miejsce. W przeciwnym razie, w perspektywie konmunikacji językowej, będą odbierane jako niefortunne, zaś w perspektywie psychologii odbioru mogą funkcjonować jako mechanizmy wywolywania w odbiorcy poczucia winy z powodu przyjmowania gratulacji czy podziękowań za coś, co nie zostalo spełnione oraz wytwarzania wewnętrznego zobowiązania do wypełnienia braku.

Reklanna, w której zawarte jest entuzjastyczne podziękowanie za skorzystanie z nowej promocji, określonej oferty, kupna reklamowanego przedmiotu, wytwarza w odbiorcy rodzaj konsternacji z powodu niedopelnienia aktu grzecznościowego. Może wytwarzać poczucie winy: skoro ktoś nam za coś dziçkujc, należało to coś uczynić. Formuła grzecznościowa angażuje nas w obecne w ludzkich kulturach zobowiązanie do dawania, przyjmowania oraz oddawania (wzajemności)". Gdy w komunikacie reklamowym pojawia się formula grzecznościowa podziękowania za zakup, którego odbiorca jeszcze nie zrobil, skorzystanie z oferty, z której jeszcze nie skorzystal, odbiorca wciągnięty zostaje w relację: konwencjonalna sytuacja grzecznościowa - zwrot grzecznościowy ${ }^{7}$ (na przykład przysługa, podarunek - podziękowanie; wyrządzenie krzywdy czy niestosowność — przeprosiny), przy czym odwrócenie porządku działań staje się sposobem wywierania wpływu na decyzje podejmowane przez odbiorcę.

\footnotetext{
"Pisze o tym między innymi R. Ciakdini. op. cit. (zob. rozdz. Reguta n'adjemmości). Autor powoluje siç też na praç M. Maussa, The' Gift, London 1954.

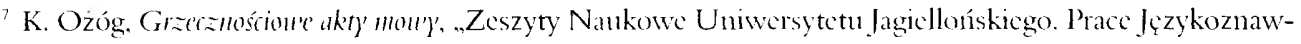
cze", z. 79, Kraków 1984, s. 1+9.
} 
W reklamie często mamy do czynienia z rozbieżnościami między tym, co użyte dosłownie i tym, co sugerowane. I tak, pojawiające się w haslach obraźliwe wyrazy: „Nie bądź głupi, kup X”, czy: „Tylko wariat nie skorzysta z tej promocji” — nie mają na celu obrażenia odbiorcy, a wręcz przeciwnie, można tu mówić o jakimś rodzaju troski o odbiorcę czy ostrzeganiu go przed popelnieniem blędu ${ }^{\star}$. Podobnie zwroty w stylu: „Będziesz wariatem, jeśli nie skorzystasz z tej promocji” jako zdania warunkowe, niejako zawieszają obraźliwe określenie odbiorcy, uzależniając jego aktywację od podjętej przez odbiorcę decyzji. Jednocześnie, posłużenie się wyrazami obraźliwymi, silnie nacechowanymi emocjonalnie służy przyciągnięciu uwagi odbiorcy, sprowokowaniu go do dzialania. Taką funkcję pełni hasło „Media Markt. Nie dla idiotów" w powiązaniu z poprzedzającymi go scenkami filmowymi, w których ignorancja bohatera jest źródtem komizmu sytuacyjnego i przyczyną komentarza: „Ten mężczyzna nie kupuje w Media Markt". Oczywistość prezentowanych sytuacji i łatwość oceny działań bohatera scenek reklamowych stawia odbiorcę po stronie tych, którzy wiedzą więcej, a tym samym tych, którzy kupują w reklamowancj sieci sklepów.

Formuly grzecznościowe obudowują często inne akty, są też źródłem wspomnianej już gry prowadzonej z odbiorcą. Użycie zwrotów grzecznościowych w funkcji innej niż grzecznościowa zwiększa siłę oddziaływania przekazu. Aktywizuje intelektualnie, skłaniając do rozpoznawania przesunięć znaczeniowych komunikatu. I tak, dla przykładu, w zamieszczonej w „Newsweeku” reklamie telewizyjnego kanału informacyjnego CNN w haśle: „Wybacz nam, że o wszystkim (co się wydarza) dowiadıjemy się przed tobą", formułą wyrażanego żalı czy przeprosin obudowuje się samozadowolenie i pozytywuą autoprezentację. Innym przykladem tego typu uzyć formuł grzecznościowych mogą być przyklady humorystycznych parafraz reklam. Po cyklu billboardów z hasłami: „Czechom gratulujemy Pragi”, „Niemcom gratulujemy Oktoberfestu”, „Anglikom gratulujemy Shakespeare'a” i na koniec: „Polakom gratulujenı Ży'u'a" pojawiły się w Internecie prześmiewcze: „Polakom gratulujemy żywca” (z obrazkiem przedstawiającym trzodę chlewną), czy na łamach tygodnika "Nie” ironiczne „Polakom gratulujemy przekrętów”.

Powiązanie formy rozkaźnikowej z sugerowaną czy wyrażaną dosłownie troską o odbiorcę powoduje łagodzenie nakazu. Posłuzenie się hasłami w stylu: „Podaruj sobie odrobinę luksusu”, „Zadbaj o siebie”, „Wéź sprawy w swoje ręce” shuzy odsunięciu formy dyrektywnej od bezpośredniego powiązania z przedmiotem reklamy. Elementem pośredniczącym między formułą dyrektywą i reklamowanym przedmiotem jest tu deklarowana dbałość o odbiorcę która ukazywana jest jako pozostająca w relacji realnego związku (relacji metonimicznej', z przedmiotem reklamy.

Innym sposobem lagodzenia dyrektywnych formul językowych (rozkazów, nakazów. jest powiązanie ich z grzecznościowymi (uprzejmościowymi) treściami zawieranymi w obra. zie czy dźwięku. Forma rozkaźnikowa, w zależności od tonu wypowiedzi, tembru głosu

\footnotetext{
"Nic ozmacza to oczywiście. że nic istnicje cala grupa reklan, których celem jest sprowokowanie odbiorcy d" dzialania takze za pośrednictwen obrazenia go.
} 
stopnia głośności, może zabrzmieć jak zachęta, prośba czy obictnica. Dystans, który związany jest $z$ formami dyrektywnymi, może być redıkowany chociazby przez posłużenie się w reklamie telewizyjnej szeptem, który często wprowadza do reklamy intymność i oddziałuje na odbiorcę przyblizająco". Podobnic rozkaz zawarty w sferze wypowiedzi językowej może być lagodzony sposobem organizacji świata przedstawionego, muzyką, rodzajem zastosowanych zdjęć. W ugrzecznieniu przekazu moga uczestniczyć odpowiednio dobrana muzyka, stopień nasycenia i tonacja barw (na przykład odwolanic się do barw ciepłych) czy zastosowanie ruchu zwolnionego. Oznacza to, że grzeczność i niegrzeczność w reklamie nie są wyłącznie domeną wypowiedzi slownych, ale w ich ksztaltowaniu biorą udział inne - charakterystyczne dla danego mediun - semiosfery, a także zdarzenia rozgrywające się w świecie przedstawionym przekazu reklamowego.

Eagodzenie rozkazu może odbywać się też na drodze powiązania zawartego w warstwie słownej nakazu z określonym wizerunkiem osoby czy ukazaniem sytuacji prezentujących postawę grzeczności czy stosowności. Grzeczność i stosowność, podobnie zreszta jak i niestosowność, mogą ujawniać się w sposobie zachowania bohatera, jego mimice, ubiorze czy prezentowanej w reklamie scence. Częstym sposobem na zlagodzenie dyrektywnego tonu czy też niestosowności jest odwoływanie się do humoru. Za przykład posłużyć może cykl telewizyjnych reklam zakładów sportowych, w których formula nakazu ,obstawiaj zakłady sportowe" oraz niestosowne zachowanie bohatera, lagodzone są humorem.

Tak jak grzeczność i stosowność, wpisıją̧c się w realizację zasady deconmm, stają się gwarantem porządku, tadu i kojarzoncj z nimi clegancji, tak niestosowność, łamiąc tę zasadę, aktywizuje oddziaływanie emocjonalne. Niestosowność służy uczynieniu tego, co znane oryginalnym, ukazaniu go z nowej perspektywy. Powtarzające się wielokrotnie w reklanie grzeczność i stosowność stopniowo prowadzą do znużenia odbiorcy. Nie łączą się z emocjami, nie przyciągają uwagi i nie zapisują się na długo w pamięci. Zjawisko to pogł̨̧bia istnienie znacznej konkurencji reklam opartych na podobnych pomyslach, reklamujących w podobny sposób konkurencyjne produkty. Dlatego twórcy niektórych reklam, chcąc przyciągnąć uwagę odbiorcy, odwohują się do niestosowności czy niegrzeczności, choć z negatywnym odd ziaływaniem w reklamie związane jest pewne niebezpieczeństwo. Oto pobudzenie negatywnych emocji może prowadzić do przeniesienia ich na przedmiot reklamy, który może być zapaniętany jako ich przyczyna, a więc to, czego należy unikać.

Częstym chwytem reklamowym jest operowanie skandalem. Wykorzystanie śmiałej, tamiącej tabu fotografii Oliviero Toscaniego w reklamach firmy odzieżowej przyniosło slawę firmie Benetton. Szokowały nie tyle same zdjęcia, co wykorzystanie ich (jak choćby budzących grozę, współczucic zdjęć dokumentalnych) do celów reklamy komercyjnej. Widok czlowieka umierająceğo na AIDS w obecności zgromadzonej wokól jego łóżka, doświadczającej jego cierpienia rodziny, żołnierza trzymającego ludzką kość, zakrwawionych ubran zabitego nie wzbudzilyby aż takiej dyskusji, gdyby pojawiły się na wystawie fotografii reportażowej. Użyte 
komercyjnie, odbierane byly jako niestosowność, jako posłużenie się świadectwem ludzkiego cierpienia, okrucieństwa, bezwzględności w celı zareklamowania firmy odzieżowej, mimo iż - paradoksalıie - sam ich twórca deklarował postawę przeciwną. Ukazanie okrucieństw i nietolerancji współczesnego świata mialo - według Toscaniego - służyć wyrażeniu sprzeciwu wobec reklamy idealizującej rzeczywistość i przez to falszującej ją. Miało ukazywać reklamę jako przekaz głęboko humanistyczny - pobudzający do dyskusji na tematy istotne spolecznie" ${ }^{\prime \prime}$.

W swoim rozumowaniu Toscani pomijal fakt, iz reklama komercyjna jest gatunkiem w znacznej mierze skonwencjonalizowanym, którego wyznacznikiem jest perswazja pozostająca $\mathrm{w}$ bezpośrednim związku z reklamowanym produktem, co skłania do interpretacji każdego zastosowanego w niej elementu jako chwytu reklamowego. Dlatego oburzenie i sprzeciw wzbudzały fotografie przedstawiające calujących się księdza i zakonnicę, czarnoskórą kobietę karmiącą biate dziecko, czy kopulujące konie. Za każdym razem motywem uzasadniającym całość było skontrastowanie bieli i czerni. Kolory stanowiły odwołanie do barwy, która jest ważnyın elementem organizującym sposób prezentowania się reklamowanej firmy odzieżowej. W efekcie dzialanie reklamowe oparte zostało na poetyce skandalı, potrójnej niestosowności, polegającej po pierwsze na upowszechnianiu widoku tego, co nie mieści się w panujących normach zachowań; po wtóre - na powiązaniu prowokujących przedstawień, istotnych tematów społecznych, etycznych z komercją, codziennością; i wreszcie na grze polegającej na możliwości manipulowania hierarchią ważności, do jakiej zachęca zestawianie za każym razem dwóch tematów: ważnego spolecznie problemu i układu barw.

Odwrócenie hierarchii ważności może być odbierane jako obraźliwe wobec pantyących norm obyczajowych i społecznych — prowokować i zlościć ${ }^{\prime \prime}$, a tym samym pobudzać emocjonalnie, silnie oddziałując na pamięć odbiorcy. To, czenuu towarzyszą silne emocje — zauważają B. Reeves i C. Nass — szybciej i głębiej zapada w pamięć:

Pobudzenie jest ważne dla ludzkiej pamięci, bez względu na to, czy doświadczenie ma charakter medialny, czy nie ${ }^{12}$.

Odwołanie się do niestosowności w reklamie służy zatem przyciąganiu uwagi odbiorcy, a także utrwalaniu w jego pamięci reklannowanej marki. Do zabiegu prowokacji odwołują się hasła reklamowe oparte na aluzjach seksualnych, na przykład „Znam najnowsze techniki” (odtwarzacz MP3), „Whóż mi” w reklamie kopertownic. Warto tu dodać, że prowadzone w mediach dyskusje na temat granic stosowności w reklamie i lamania tabu obyczajowego w reklamach okréslonych firm dawaly efekt zbieżny z tym, jakiego oczekiwały te firmy - nagłośnienia reklamowanej marki, utrwalenia jej nazwy w pamięci odbiorcy.

\footnotetext{
"Zob. O. Toscani. Reklama, uśmichluniçtésiceruo, tl. M. Misiorny, Warszawa 1995.

"O tym. ż prowokowanie do zlości przez niestosowne zachowanie siç jest skutecznym sposobem oddziaływania na przeciwnika. pisal chociazby Artur Schopenhauer (zob.: A. Schopenhauer. Erystyka cz)li sztuka prou'udzenia sporón. tl. B. i L. Konorscy. przedm. T. Kotarbiński, Warszawa 2(0)2. s. 71).

I: B. Reeves. C. Nass, Media i lendzic, tt. H. Szczerkowska. Warszawa 2000), s. 163.
} 
Nie bez znaczenia jest też i to, że reklama jako przekaz kultury masowej uczestniczy w przesuwaniu granic między tym, co uznawane za stosowne, grzeczne, a tym, co uchodzi za niestosowne, niegrzeczne czy wręcz wulgarne. I tak na przykład zachwalanie siebie czy mówienie na glos o tym, co mieści się w sferze tabu (jak zaparcia, impotencja, seks, przemoc w rodzinic, menstruacja), dawnicj uchodzące za naganne, obecnic przesunęło się w sferę tego, czemu udziela się przyzwolenia przy spełnieniu określonych warunków (w tym: mówienia prawdy, ale nie epatowania przesadną dosłownością, zwłaszcza jeśli odbiorcami przekazı mogą być dzieci; ograniczenic występowania treści uchodzących za wątpliwe etycznie do określonych gatunków i form tekstowych).

Ciekawym zjawiskiem w reklamic jest odwoływanie się do tonu obraźliwego nie w stosunku do grupy docelowej, lecz w stosunku do tych, którzy mogą być przedmiotem żartu, niechęci lub pogardy dla tej grupy. Za przykład moga posłużyć reklany kicrowane do ludzi młodych, gdzie przedmiotem żartu (lub wręcz pogardy) są dorośli czy wręcz ludzie starsi, jak miało to miejsce w reklamach napoju Frngo. Innego przykładu dostarczaja slogany kicrowane do mężczyzn, które mogą być przez kobiety postrzegane jako obraźliwe, na przykład hasło „Dla nicj rzucisz swoją starą” (w reklamie drukarek) czy: „Nikt nie zaszkodzi mojemu silıikowi, nawet ona" (reklama oleju silnikowego) - hasto, które doczekalo się zresztą riposty: "Nikt nie zaszkodzi mojemu silnikowi, nawet on".

Podsunowując, można stwierdzić: podczas gdy niestosowność, prowokacja, skandal, obliczone na silne oddziaływanie emocjonalne (i podporządkowane perswazji emocjonalnej), wykorzystywane są w reklamie — zwłaszcza wówczas, gdy jej celem jest zwrócenie uwagi odbiorcy na reklamowaną markę, wydobycic jej spośród innych konkurencyjnych marek i zapisanie w pamięci krótkotrwałej — to grzeczność i stosowność, etycyzując i estetyzując reklamę, odwołując się do potrzeby bezpieczeństwa, pewności, obcowania z tym, co kulturowo akceptowane, shuzą przede wszystkim wytworzeniu pozytywnego wizerunku przedniotu reklamy i zapisaniu go w pamięci dlugotrwalej. 